\title{
THE TURKS AND CAICOS ISLANDS
}

Area: 430 sq. km

Population: 8100

Capital: Grand Turk

Governor: C. J. Turner

The Turks and Caicos Islands consist of over 30 small cays, only 6 of which are permanently inhabited.

The Royal Turks and Caicos Islands Police Force has 90 men under the authority of a Chief of Police. Headquarters is at Grand Turk and there are police stations at Providenciales and South Caicos islands.

The Police Training Centre at Grand Turk gives basic instruction to candidates. More advanced or specialized training is provided in Barbados or the UK.

Police Headquarters, Grand Turk (2299)

Police Training Centre, Grand Turk (2299) 